岩石鍍物䤲床学会誌

51 巻 4 号, 1964 年

\title{
TWO KINDS OF WHITE MICA FOUND IN THE KOMORI ULTRABASIC MASS, KYOTO PREFECTURE, JAPAN*
}

\author{
Yoshimasu Kuroda, Mitsuo Sato \\ Tolyo University of Education \\ Yoshio OGURA \\ Resources Research Institute \\ and \\ EI-ICHI HASHIDA \\ Hurukawa Mining Co. Ltd.
}

\section{INTRODUCTION}

In the course of the study of the Kômori ultrabasic mass, one of the writers (Y.K.) found two kinds of white mica, coexisting stably in one rock section under the microscope. One of them is clouded or dusty mica and the other is clean mica. The rock, consisting of the white mica, zoisite and sodic plagioclase, occurs as network veins or small lenses of several $\mathrm{cm}$ width in pyroxenite. However, in the field these two kinds of white mica could not be distinguished with each other. The field work was done by Y.K. and E.H.

Since the laboratory work has been carried by Y.K., M.S. and Y.O., the peculiar character of the clean mica becomes clear. The writers should like to report its characters and some considerations on the solid solution relation between paragonite and margarite. Petrological report on the ultrabasic mass itself will be reported in detail in another paper.

\section{OCCURRENCE}

The Komori ultrabasic mass is located in the northern side of the Maizuru zone, which is the structural zone, dividing the Paleozoic formation of the Inner Zone of the Southwest Japan into two parts, the Tanba belt characterized by the non-metamorphic Paleozoic formation and the Sangun belt characterized by the rocks of glau-

* Papers from Ultramafic Rock Subgroup of Plutonism Research Group, No. 1.

(Manuscript received, January 26, 1964) 
cophane-schist metamorphism. The mass is big lenticular shaped, having several $\mathrm{km}$ width and more than $10 \mathrm{~km}$ length. It intruded into Paleozoic formation and was intruded by the Mesozoic granite (Fig. 1). To Paleozoic formation it may effect a weak contact

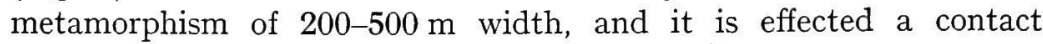
metamorphism of 1-2 km width by the granite.

It is composed mainly of serpentinized dunite, being accompanied by small amounts of peridotite, pyroxenite and gabbro, which are probably later stage products of the crystallization of the mass in the order as mentioned above. In the mass are there ore veins, consisting of chalcopyrite, pyrite, pyrrhotite and cubanite etc.. They may be related originally to the ultrabasic magma. Besides these there are rodingite, albitite and white mica-zoisite rock.

These rocks are often seen in pyroxenite or gabbro as small pockets, lenses and veins. Although there is the opinion that the origin of such rocks is metamorphic or metasomatic, from their mode of occurrence they seem to be the latest products of the consolidation

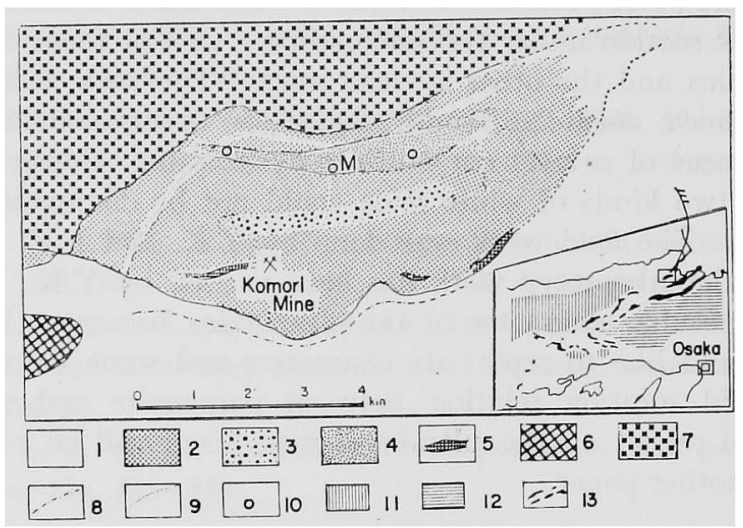

Fig. 1. Geological map of the Kômori district. (In this map various datas of the writers, S. Igi, H. Kano, K. Nakazawa, T. Shiki et al. as mentioned in the references are compiled by the authors.)

Large quadrate for the the main map. 1; Paleozoic formation, 2 ; serpentinized dunite, 3 ; serpentinized peridotite, 4 ; pyroxenite, 5 ; gabbro-diorite, 6; gabbro of the forerunner of the granite, 7 ; Mesozoic granite, 8; the line, of which inside is contact aureole of the ultrabasic mass, 9; the line, of which inside is contact aureole of the granite, 10; localities of the white micas-zoisite rock. Small quadrate for the index map. 11; Sangun belt, 12; Tanba belt, 13; ultrabasic-basic rocks of the Maizuru zone. 
of ultrabasic magma. It is well known that in the latest stage of the consolidation of granitic magma minor veins or dikes of such silicic rocks as pegmatite, aplite and quartzose rocks are formed. The writers consider that at the latest stage of the consolidation of ultrabasic magma such minor bodies enriched in $\mathrm{Ca}$ and $\mathrm{Al}$ are formed. This is very important thing, and will be stated in another paper.

The white mica-zoisite rock under consideration is composed of zoisite, white mica and albitic plagioclase. The modal composition of the rock is as follows; zoisite $72.2 \%$ clouded mica

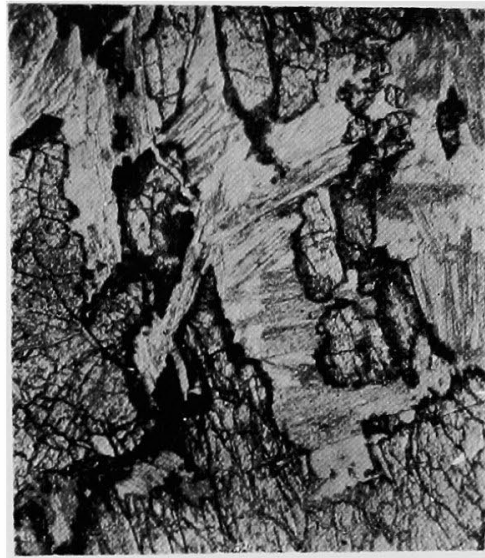

Fig. 2. Microscopic photograph of the white micas-zoisite rock. $(\times 30$, parallel nicol)

High relief mineral is zoisite. Clear part is the clean mica and greyish part is the clouded mica. $13.2 \%$, clean mica $12.7 \%$ and albitic plagioclase $1.9 \%$. Texture is rather metamorphic or aplitic. (Fig. 2)

Among the crystals of zoisite, both of $\alpha$-type and $\beta$-type are

Table 1. Chemical analysis and optical properties of zoisite.

\begin{tabular}{|c|c|c|}
\hline & wt. \% & $\begin{array}{c}\text { calculated for } \\
(\mathrm{O}, \mathrm{OH})=13\end{array}$ \\
\hline $\mathrm{SiO}_{2}$ & 39.68 & 3.09 \\
\hline $\mathrm{TiO}_{2}$ & 0.01 & $\overline{1}$ \\
\hline $\mathrm{Al}_{2} \mathrm{O}_{3}$ & 33.85 & 3.10 \\
\hline $\mathrm{Fe}_{2} \mathrm{O}_{3}$ & 1.83 & 0.10 \\
\hline $\mathrm{FeO}$ & 0.00 & - \\
\hline $\mathrm{MnO}$ & 0.03 & - \\
\hline $\mathrm{CaO}$ & 22.68 & 1.89 \\
\hline $\mathrm{MgO}$ & 0.00 & - \\
\hline $\mathrm{Na}_{2} \mathrm{O}$ & 0.51 & 0.06 \\
\hline $\mathrm{K}_{2} \mathrm{O}$ & 0.51 & 0.04 \\
\hline $\mathrm{H}_{2} \mathrm{O}(+)$ & 0.25 & 0.13 \\
\hline $\mathrm{H}_{2} \mathrm{O}(-)$ & & \\
\hline Total & 99.53 & \\
\hline $2 \mathrm{~V}$ & \multicolumn{2}{|l|}{$\fallingdotseq(-) 0^{\circ}$} \\
\hline$\alpha_{D}$ & \multicolumn{2}{|c|}{$1.694( \pm 0.002)$} \\
\hline$\gamma_{D}$ & \multicolumn{2}{|c|}{$1.700( \pm 0.002)$} \\
\hline
\end{tabular}

(Analyst: H. Kurosawa) 
seen. The optical properties and chemical composition of the zoisite are shown in Table 1 . Its grain size is $0.3-0.2 \mathrm{~mm}$.

The composition of plagioclase is An 8-20. It is untwined in almost case but is rarely twined after albite law.

\section{WhITE Mica}

The clouded mica and the clean mica are clearly distinguished under the microscope in almost case. In some case they are intergrown with each other. The clouded mica is not an altered product from the clean mica, but is stable and independent mineral.

Table 2. Chemical analyses of various white micas.

\begin{tabular}{|c|c|c|c|c|c|}
\hline & 1 & 2 & 3 & 4 & 5 \\
\hline $\mathrm{SiO}_{2}$ & 42.32 & 45.91 & 46.20 & 29.57 & 39.72 \\
\hline $\mathrm{TiO}_{2}$ & 0.01 & 0.17 & 0.30 & $\overline{0}$ & $\overline{-0}$ \\
\hline $\mathrm{Al}_{2} \mathrm{O}_{3}$ & 40.66 & 34.50 & 39.58 & 49.97 & 41.50 \\
\hline $\mathrm{Fe}_{2} \mathrm{O}_{3}$ & 0.27 & 1.17 & 0.79 & 2.94 & 0.75 \\
\hline MnO & 0.01 & n.d. & $<0.02$ & $0 . \overline{22}$ & 0.35 \\
\hline $\mathrm{MgO}$ & 0.65 & 0.95 & 0.14 & 0.34 & 0.91 \\
\hline $\mathrm{CaO}$ & 4.86 & 2.27 & $<0.1$ & 10.89 & 3.28 \\
\hline $\mathrm{Na}_{2} \mathrm{O}$ & 3.37 & 2.01 & 6.76 & 0.92 & 5.64 \\
\hline $\mathrm{K}_{2} \mathrm{O}$ & 3.98 & 8.83 & 0.62 & $0.39 *$ & 0.68 \\
\hline $\mathrm{P}_{2} \mathrm{O}_{5}$ & 0.00 & n.d. & 0.16 & - & $0.62 * * *$ \\
\hline $\begin{array}{l}\mathrm{H}_{2} \mathrm{O}(+) \\
\mathrm{H}_{2} \mathrm{O}(-)\end{array}$ & $\begin{array}{l}2.87 \\
0.43\end{array}$ & $\begin{array}{l}3.96 \\
0.34\end{array}$ & $\begin{array}{l}4.81 \\
0.10\end{array}$ & 4.81 & $\begin{array}{l}5.60 \\
1.01\end{array}$ \\
\hline Total & 99.94 & 100.38 & 99.88 & 100.05 & 100.25 \\
\hline \multicolumn{6}{|c|}{ Calculated for $(\mathrm{O}, \mathrm{OH})=12$} \\
\hline $\mathrm{Si}$ & 2.82 & 3.06 & 2.96 & 1.97 & 2.59 \\
\hline $\mathrm{Ti}$ & - & 0.01 & 0.02 & - & - \\
\hline $\mathrm{Al}$ & 3.22 & 2.72 & 2.98 & 3.91 & 3.19 \\
\hline $\mathrm{Fe}^{3+}$ & 0.02 & 0.06 & 0.04 & 0.15 & 0.04 \\
\hline $\mathrm{Fe}^{2+}$ & 0.03 & 0.02 & 0.02 & $\bar{a}$ & 0.02 \\
\hline $\begin{array}{l}\mathrm{Mn} \\
\mathrm{Mg}\end{array}$ & $0 . \overline{06}$ & $0 . \overline{10}$ & $\begin{array}{l}0.01 \\
0.01\end{array}$ & $\begin{array}{l}0.01 \\
0.03\end{array}$ & $0 . \overline{09}$ \\
\hline $\mathrm{Ca}$ & 0.35 & 0.17 & - & 0.72 & 0.23 \\
\hline $\mathrm{Na}$ & 0.43 & 0.26 & 0.84 & 0.12 & $\begin{aligned} & \text { Sr } 0.02 \\
& 0.71\end{aligned}$ \\
\hline $\mathrm{K}$ & 0.34 & 0.75 & 0.05 & Li 0.10 & 0.05 \\
\hline$(\mathrm{OH})$ & 1.30 & 1.78 & 2.05 & 2.13 & 2.44 \\
\hline
\end{tabular}

(* $\left.\mathrm{Li}_{2} \mathrm{O}, * * \mathrm{BaO}, * * * \mathrm{SrO}\right)$

1: Kômori, (Analyst H. Kurasawa)

2: Kômori, (Analyst $\mathrm{Y}$. Ogura)

3: Bessi, S. Banno, (1960)

4: Chester, G. Koch, (1935)

5: Northern Caucasus, Afanasev, G. D. and Aidinyan, N. Kh. (1952) 
The clouded feature of the clouded mica is based on its large amounts of minute liquid inclusion. Grade of the clouding is variable. The grain size of both mica is $0.1-1.0 \mathrm{~mm}$ in length.

The writers tried to separate not only white mica from the host rock but also the clean mica and the clouded mica with each other by heavy solutions, but the latter is very difficult. From two rock specimens the writers separated the white mica and get fairly purified samples for chemical analyses. In the Table 2 the chemical analyses of these two smaples are shown. In this table No. 1 is the sample comparatively rich in the clean mica (probably more than $65 \%$ in mode) and No. 2 is the sample slightly rich in the clouded mica (probably more than $53 \%$ in mode).

In the treatment of the separation it seemed that the clouded mica was slightly lighter than the clean mica.

Optical properties of these white mica are listed in Table 3. From this properties the clouded mica may be similar to muscovite and the clean mica may be similar to paragonite. However, since muscovite and paragonite are similar to each other in optical properties, only from the optical properties the clouded mica and the clean mica are not be identified.

In Fig. $3 \mathrm{X}$-ray powder charts of two analysed micas are shown. From this figure paired peaks of the reflection of (005) are clearly recognized; one of the pair may be the reflection of the clouded mica and the other may be the reflection of the clean mica. The left hand side of the paired peaks is close to that of muscovite and the right hand side is close to that of paragonite. Numbers in this figure are same to those in Table 2. It is necessary to note that the intensities of the peaks of No. 1 and No. 2 are different with each other. That is, the right hand peak is stronger and the left hand peak is weaker in the case of No. 1 than in the case of No. 2. This may be due to the modal composition of these sample; No. 1 is rich in the clean mica and No. 2 is rich in the clouded mica. If it is true, the left hand peak is the reflection from the clouded mica and the right hand peak is the reflection from the clean mica.

From the chemical analyses it is noteworthy that $\mathrm{Ca}$ is very

Table 3. Optical properties of the white micas.

\begin{tabular}{c|l|l}
\hline & clouded mica & \multicolumn{1}{c}{ clean mica } \\
\hline$\beta$ & $1.588( \pm 0.002)$ & $1.613( \pm 0.002)$ \\
2 V observed & $(-) 0-30^{\circ}$ & $(-) 38^{\circ}$ \\
\hline
\end{tabular}



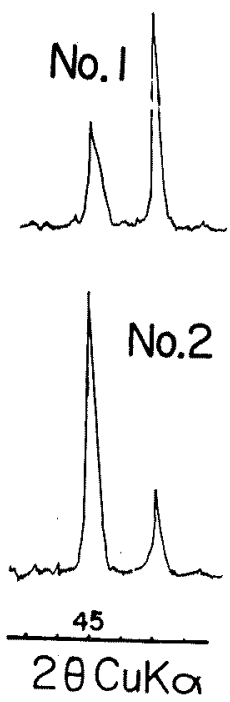

Fig. 3. X-ray powders charts of the analysed samples. (Numbers are same to those in Table 2.) rich in comparison with common white mica. As mentioned above one of two kinds of white mica, the clouded one, may be similar to muscovite and the other, the clean one, may be close to paragonite. If it is true, $\mathrm{Na}$ and $\mathrm{K}$ come from the clean mica and the clouded mica respectively. However, it is obscure from where $\mathrm{Ca}$ comes. The writers, at first, doubted it might come from zoisite, being impurely mixed in the analysed samples, so the writers tested carefully the purity of the analysed samples under the microscope. But the samples did not contain zoisite. The writers confirmed that $\mathrm{Ca}$ should come from the white mica.

In both analyses the ratio $\mathrm{Na}$ : $\mathrm{Ca}$ is nearly same, though total amount of $\mathrm{Na}+\mathrm{Ca}$ is different. $\mathrm{Na}+\mathrm{Ca}$ is larger and $\mathrm{K}$ is smaller in the case of No. 1 than in the case of No. 2. The writers consider that this reflects the difference of the modal compositions of two white micas and the difference of the intensities of the $\mathrm{x}$-ray powder charts also reflects the difference of the modal compositions. These data are normally correlative. From this point of view the writers come out the conclusion that $\mathrm{Ca}$ comes from the clean mica.

$c \sin \beta$ of the white mica is calculated as shown in Table 4 . From the data, too, the clouded mica is clearly muscovite. $\mathrm{c} \sin \beta$ of the clean mica is $19.18 \dot{A}$. According to Banno (1960) $\mathrm{c} \sin \beta$ of paragonite is $19.24 \dot{A}$. If this is true, $c \sin \beta$ of the clean mica shows the intermediate value between paragonite $(19.24 \AA)$ and margarite $\left(19.08^{*}-19.11 \dot{A}\right)$. From its value it is possible to consider that the composition of the clean mica is certainly intermediate between paragonite and margarite.

* This data was calculated by the writers from the X-ray powder data of margarite given by Dr. A. Miyashiro. Its locality is Chester, Massachusets, U.S.A.. This value is same to the value $(19.11 \mathrm{~A})$ in Winchel (1951). 


\section{A Consideration on White Mica}

As margarite and paragonite are not common, until now, in natural rocks, they have not been well investigated. For example, the reason why margarite has not been belonged to common mica group is not clear. It has been belonged to "brittle mica". The relation between paragonite and muscovite is not clear, too. Paragonite, recently, has been found in glaucophane-schist region and the Dalradian type metamorphic terrane (Rosenfeld 1958, Banno 1960, Kuroda and Ogura 1963, McNamara 1963), but its significance is not so clarified.

From above mentioned data, the writers consider that the clean mica under consideration may be an intermediate mica between paragonite and margarite. That means that there exists a solid solution relation between paragonite and margarite under some favorable condition. As mentioned before (Kuroda and Ogura 1963), paragonite and muscovitc cnexist stably in some metamorphic rocks. In that case paragonite conposition is fewer than muscovite composition $\left(\mathrm{Na}_{2} \mathrm{O}=1.07-1.53 \%, \mathrm{~K}_{2} \mathrm{U}=8.57-10.24 \%\right)$, but they do not make a solid solution in muscovite. This is reasonable from the diagram for the subsolidus region of the muscovite-paragonite join constructed by Eugster and Yoder (1955).

In the present case muscovite and the clean mica of paragonitemargarite series coexist. However, paragonite and margarite do not coexist, but make a solid solution. There are not only almost pure margarite (Koch 1935) and paragonite (Rosenfeld 1958, Banno 1960), but also sodium margarite (Afanasev and Aidinyan 1952 etc.) (Table 4). Their significance or relation in petrology is scarecely discussed. However, some possibility that comparatively large

Table 4. $c \sin \beta$ of various white micas.

\begin{tabular}{l|c}
\hline & $c \sin \beta(\AA)$ \\
\hline clouded mica (Kômori) & 19.97 \\
clean mica (Kômori) & 19.18 \\
muscovite (calculated from & 19.94 \\
the data in Winchel 1951) & 19.24 \\
paragonite (Bessi, Banno 1960) & 18.99 \\
paragonite (Deer et al. 1962) & 19.08 \\
margarite (Chester, the writers) & 19.11 \\
margarite (calculated from & \\
\hline the data in Winchel 1951) &
\end{tabular}


solid solution field exists between paragonite and margarite is concerned.

Chemical formulas of white mica group are writen as follows; muscovite $\mathrm{K}_{2} \mathrm{Al}_{3} \mathrm{Si}_{3}(\mathrm{O}, \mathrm{OH})_{12}$, paragonite $\mathrm{Na}_{2} \mathrm{Al}_{3} \mathrm{Si}_{3} \quad(\mathrm{O}, \mathrm{OH})_{12}$ and margarite $\mathrm{Ca}_{2} \mathrm{Al}_{4} \mathrm{Si}_{2}(\mathrm{O}, \mathrm{OH})_{12}$. It is interesting to note that there is a correspondence between the chemistry of these white micas and those of feldspar group; that is, muscovite-potassium feldspar, paragonite-albite, margarite-anorthite. Moreover, potassium feldspar hardly make a solid solution with albite except under high temperature condition, but albite and anorthite easily make a solid solution, plagioclase.

However, as there are only few data on these white mica group, the writers cannot conclude any definite opinion. As will be stated in another paper, white mica group and zoisite group in the course of the crystallization of ultrabasic magma will show an important behaviour as the behaviour of feldspar group in the course of the crystallization of granitic magma, especially at later stage.

\section{ACKNOWLEDGEMENTS}

The writers wish to thank Plutonism Research Group, especially Dr. Maso Gorai of Tokyo University of Education for the reading of this manuscript and encouragement. They wish to thank Dr. Akiho Miyashiro of University of Tokyo for giving the margarite specimen of Chester and suggestion. The writers are much obliged to Dr. Sachio Igi of the Geological Survey of Japan for many advices and lending unpublished data. They also express their gratitude to $\mathrm{Mr}$. Hajime Kurasawa of the Geological Survey of Japan and stuffs of the Kômori Mine of Nippon Kôgyo Co. Ltd. for their kind assistances.

\section{REFERENCES}

Afanasev, G.D. and Aidinyan, N. Kh. (1952), On natron margarite from northern Caucasus, Bull. Acad. Sci. USSR, Geol. Ser. 2, 138*

Banno, S. (1960), Notes on rock-forming minerals (12), Finding of paragonite from the Bessi district, Sikoku, and its paragenesis, Jour. Geol. Soc. Jap., 66, 123 130.

Deer, W.A., Howie, R.A. and Zussman, J. (1962), Rock forming minerals, 3, Longmans.

Eugster, H.P. and Yoder, H.S. (1955), The join muscovite-paragonite, Carnegie Inst. Washington, Ann. Rep, 1954 1955, 124 126.

Igi, S. (in press), Geological map of Komori, 1/50,000. Geol. Surv. Jap. 
Kano, H, Nakazawa, K., Igi, S. and Shilki, T. (1959), On the high grade metamorphic rocks associated with the Yakuno intrusive rocks of the Maizuru zone, Jour. Geol. Soc. Jap., 65, 267 271. (in Japanese with English abstract)

Kano, H., Nakazawa, K, and Shiki, T. (1961), Considerations on the Permian back grounds of the Maizuru district judging from the conglomerate, Jour. Geol. Soc. Jap., 67, 463 475. (in Japanese with English abstract)

Koch, G. (1935), Chemische und physikalisch-optische Zusammenhange innerhalb der Sprodglimmergruppe, Chemie der Erde, 9, 453.*

Kuroda, Y. and Ogura, Y. (1963), Epidote amphibolites from the northern Abukuma plateau, Sci. Rep. Tokyo Kyoiku Daigaku, Sec. C, 8, 245 268.

McNamara, M.G. (1963), Paragonite from the Dalradian. Nature, 197, 1193.

Nakazawa, K. (1961), On the so-called Yakuno intrusive rocks in the Yakuno district, Southwest Japan, Jubilee publication in commemoration of Prof. Jiro Makiyama, 149 161. (in Japanese with English abstract)

Rosenfeld, J.L. (1958), Paragonite in the schist of Glebe Mountain, southern Vermont. Am. Min., 41, 144 147.

Winchel, A.N. (1951), Elements of optical mineralogy, John Wiley, New York.

* As the writers cannot find the original papers, the data refferenced here is after Deer et al. (1962).

\section{京部府, 河守鉱山付近の超塩基性岸体中に発見された 2 種類の無色雲母}

$$
\begin{aligned}
& \text { 黑田吉益・佐藤満雄 } \\
& \text { 小倉義雄・橋田栄一 }
\end{aligned}
$$

\section{摘 要}

京都府，河守鉝山付近にはダンかんらん岩がかなり大きく露出しているが，その一部 に pyroxenite があり，その中に巾数 $\mathrm{cm}$ 数 $10 \mathrm{~cm}$ の传白質脈が存在する。それは， ゆうれん石と2 種の無色雲姆からなるプライト状の組織をもつ岩石である。

2 種の無色䇪母は，微小の夜体包有物(?)をもつよこれれた感しのものと，きれいなもの とである。また, 前者は屈折祭がやや低く，後者はやや高いのではつきり区別できる。こ れらの光学性，化学成分， X線データなとを検討した結果，前者は muscovite で，後 者は paragonite と margarite の中間的なもの (固溶体)と考えた。

Euguster and Yoder $の$ muscovite-paragonite join は正しいが，化学的条件によ つては paragonite-margariteはより固溶体をつくりやすいだろうと推定した。 